УДК $355 / 359$

ПАЩУК Ю. М.

https//orcid.org/0000-0002-0631-6183

https://doi.org/10.33577/2313-5603.35.2021.44-57

\title{
ІСТОРИЧНІ АСПЕКТИ ОРГАНІЗАЦІЙНОГО ВИВЧЕННЯ I ВПРОВАДЖЕННЯ ДОСВІДУ У ЗБРОЙНИХ СИЛАХ УКРАЇНИ У «МИРНИЙ ПЕРІОД» (1991 - 2014)
}

У статті досліджено історичні аспекти створення та функціонування Системи узагальнення і поширення досвіду Збройних Сил України у „мирний період” iз моменту їх створення у грудні 1991 року по квітень 2014 року, коли розпочалася Антитерористична операція на сході нашої держави.

Потреба у дослідженні історії організаційного вивчення та впровадження у Збройних Сил України та особливостей його функціонування зумовлена, насамперед тим, що, починаючи з січня 2019 року, у Збройних Силах України здійснюється формування перспективної Системи вивчення і впровадження досвіду на основі попередньої Системи узагальнення та поширення досвіду. Важливість і актуальність цього науково-практичного завдання визначається також тим, що на сьогодні в українській історіографії відсутні дослідження, присвячені вищезазначеному питанню.

Стаття включає аналіз функціонування Системи узагальнення та поширення досвіду упродовж двох із трьох основних етапів свого становлення і розвитку відповідно до геополітичних змін і реформування Збройних Сил - етап „стагнація” (грудень 1991-травень 2013) та етап ,реформування” (травень 2013 - квітень 2014).

Розглянуто чотири основні компоненти Системи узагальнення та поширення досвіду: організаційна структура, формалізовані процедури, засоби та підготовка особового складу щодо узагальнення та поширення досвіду.

Дослідження організаційного вивчення та впровадження у Збройних Сил України здійснювалося за двома головними напрямами: вивчення досвіду підготовки військ, зокрема досвіду військових навчань національного та міжнародного рівня; вивчення досвіду застосування українських контингентів у міжнародних операціях із підтримання миру і безпеки.

На підставі цього аналізу зроблено висновок про низьку дієвість функціонування Системи узагальнення та поширення досвіду у вищезазначений „мирний період”. Одним із головних наслідків неефективності Системи було те, що у Збройних Силах України вельми повільно впроваджувалися новації за результатами вивчення як свого досвіду, так і досвіду інших держав. У результаті чого не було проведено кардинальних реформ у Збройних Силах для їх адаптації до тодішнього стратегічного середовища, а українські війська (сили) не були готові до ведення сучасних швидкоплинних воєнних операцій (дій).

Пащук Юрій Михайлович, кандидат технічних наук, доцент кафедри іноземних мов та військового перекладу Національної академії сухопутних військ імені гетьмана Петра Сагайдачного, м. Львів.

(C) Пащук Ю. М., 2021 
Ключові слова: досвід, організаційне вивчення та впровадження досвіду, процес вивчення та впровадження досвіду, Система узагальнення та поширення досвіду, Збройні Сили України.

Постановка проблеми та ї̈ актуальність. Щоб бути успішним у будь-якій діяльності, зокрема, і у військовій, необхідно насамперед здобувати відповідні знання, вивчати отриманий досвід i на основі їх аналізу вносити належні корективи у свою діяльність та постійно адаптуватися до середовища та його змін. Це стосується не тільки індивідуального рівня, оскільки, наприклад, успішність окремої військової організації (наприклад, збройні сили, вид збройних сил, рід військ, військова частина, установа, заклад, підрозділ тощо) або ж низки організацій, що мають між собою тісні міжорганізаційні зв'язки, напряму залежить від ефективності організаційного вивчення та впровадження досвіду (ОВВД) (Dyson, 2019). У рамках військової діяльності організаційне вивчення та впровадження досвіду визначено як процес, за допомогою якого військова організація використовує нові знання, отримані на підставі здобутого досвіду або ж проведених досліджень, для корегування інституційних норм, доктрин і процедур із метою мінімізації ризику повторення помилок та збільшення шансів досягнення успіхів і перемог у майбутньому (Dyson, 2020: 15).

Практичне використання напівформального i формального підходів до ОВВД було започатковано у Німеччині та Великобританії під час Першої світової війни (Dyson, 2020: 17). Подальший розвиток теорії і практики ОВВД був реалізований у роки Другої світової війни та у період розгортання ,холодної війни” у багатьох країнах, у тому числі і в Радянському Союзі (Великая Отечественная война 1941-1945 годов: 695-776; Грицююк, Евсеев, 2020: 85-100). Вперше фундаментальні засади концепції ОВВД були сформульовані американськими науковцями Річардом Сієртом та Джеймсом Марч у pоботі (Cyert, March, 1963), в якій обгрунтовано важливість створення належної організаційної структури та застосування відповідних організаційних правил і процедур для забезпечення дієвого вивчення та впровадження досвіду (ВВД).

У Збройних Силах (ЗС) України з грудня 1991 року, з моменту їх створення, до грудня 2018 року діяла Система узагальнення та поширення досвіду (СУПД), успадкована від Радянського Союзу (Пашук, Пашковський, 2019: 36). Ця Система була однією з форм організаційного вивчення і впровадження досвіду у ЗС України i визначалася як сукупність способів, методів, прийомів, а також 
відповідні організаційна структура, процедури та засоби, що застосовувалися для отримання знань і досвіду, управління ними та їх поширення (Пашук, Пашковський, 2019: 36-38). Система узагальнення та поширення досвіду пройшла три основні етапи свого становлення і розвитку відповідно до геополітичних змін та реформування Збройних Сил: стагнація (грудень 1991-травень 2013); реформування (травень 2013 - квітень 2014); адаптація (квітень 2014 - грудень 2018) (Пашук, Пашковський, 2019: 36).

Збройна агресія Російської Федерації проти України, що триває 3 2014 року, стала основним чинником і каталізатором кардинального реформування СУПД, а також створення, починаючи з січня 2019 року, перспективної Системи ВВД із забезпеченням іiї сумісності 3 відповідною Об'єднаною системою ВВД НАТО (Памук, Пашковський, 2019: 37). Оскільки формування перспективної Системи ВВД здійснюється на основі попередньої СУПД, то важливим i актуальним науково-практичним завданням $\epsilon$ дослідження історичних аспектів створення та функціонування Системи узагальнення та поширення досвіду у „мирний період” iз грудня 1991 року по квітень 2014 року, до початку Антитерористичної операції на сході України. Варто зазначити, що на сьогодні в українській історіографії відсутні дослідження, присвячені вищезазначеному питанню.

Mema cmammi - дослідити історичні аспекти створення та функціонування Системи узагальнення і поширення досвіду у період із грудня 1991 року по квітень 2014 року та проаналізувати особливості організаційного вивчення і впровадження досвіду у Збройних Силах України впродовж вказаного проміжку часу.

Виклад основного матеріалу дослідження. Після здобуття незалежності суверенна Україна розробила законодавчу та політичну основу для створення Збройних Сил України. У цьому напрямі було прийнято низку важливих документів, серед них: „Про основи національної безпеки України”, „Про Збройні Сили України”, „Про оборону України” та „Про Концепцію оборони і будівництва Збройних Сил України”. Цими Законами було визначено структуру та основні функції Збройних Сил, їх правові та організаційні принципи, зокрема і принципи формування та функціонування СУПД на базі радянської „Системы изучения опыта и доведения его до войск" (СИДО) (Великая Отечественная война 1941-1945 годов: 695-776). Результати порівняльного аналізу діяльності як СИДО, так і СУПД у мирний і воєнний час свідчать про те, що чим триваліший період для військ без участі у збройних конфліктах, 
воєнних операціях (діях), тим менше уваги приділялося розвитку та модернізації вищевказаних систем ВВД.

Період із грудня 1991 по квітень 2014 року в історії Збройних Сил України можна охарактеризувати як їх руйнування, насамперед через існуючу на той час в державі стратегічну культуру. В основі такої культури було намагання України набути нейтрального статусу у геополітичному просторі, знаходячись у буферній зоні між декількома потужними військовими та економічними центрами. Насправді ж задекларований нейтралітет України як не був підтверджений реальними гарантіями провідних глобальних гравців, так і не був забезпечений у військовому, соціальному та економічному аспектах. Так, наприклад, у 2010 році оборонний бюджет України мав становити $1,15 \%$ ВВП, проте було виділено коштів лише 0,97 \% ВВП) (Біла книга, 2011: 21). На тлі процвітання корупції та інших зловживань, в умовах хронічного недолінансування і тотального скорочення військових структур без суттєвого оновлення та модернізації озброєння і військової техніки, спостерігалося постійне зниження боєздатності та оперативних спроможностей 3С України. Вищенаведені негативні тенденції відповідним чином обумовили стагнацію СУПД, що, як і будь-яка діяльність у військовій сфері, базувалося на чотирьох „колонах” (The NATO Lessons Learned Handbook, 2016: 9): організаційна структура, формалізовані процедури, засоби та підготовка особового складу щодо узагальнення та поширення досвіду (УПД).

Власне до 2014 року у ЗС України була відсутня цілісна централізована організаційна структура підрозділів УПД, що несли б безпосередню та повну відповідальність за цей напрям діяльності і мали б чітку ієрархічну побудову вертикалі (Ісаков, Яковлев, Хлопецький, Василів, 2009: 152-155). У той період зберігалася „радянська” організаційна культура, що сформувалася ще у 1942 році у ході Другої світової війни (Великая Отечественная война 1941-1945 годов: 695-776) і була представлена чітким розподілом обов'язків між двома окремими „гілками” командування та управління, починаючи з рівня дивізії і вище:

- офіцерами оперативних відділень, відділів і управлінь, що мали здійснювати збір інформації з досвіду та іiі аналіз, а також підготовку відповідних інформаційно-аналітичних матеріалів для їх подальшого поширення; 
- офіцерами відділень, відділів і управлінь бойової підготовки, що відповідали за впровадження вивчених уроків, зокрема i передового досвіду.

Вищенаведений розподіл повноважень у здійсненні окремо першого етапу (вивчення досвіду) і другого етапу (впровадження досвіду) та недостатня координація вищевказаних органів не сприяли покращенню дієвості ОВВД у ЗС України. Безпосередню відповідальність за узагальнення досвіду несли наступні офіцери та органи, що складали основу організаційної структури СУПД:

- у військових частинах (полках, бригадах), з'єднаннях та об'єднаннях - зазвичай заступники начальників штабів, заступники начальників оперативних відділень і відділів, які додатково до своїх обов'язків відповідали за вивчення досвіду;

- на оперативному рівні - воєнно-наукові групи (2-3 офіцери) у складі оперативних управлінь військових округів (до 1998 року) та оперативних командувань (з 1998 по 2007 рр.);

- на оперативно-стратегічному рівні - воєнно-наукові відділи (2-4 офіцери) у складі оперативних управлінь командувань видів і родів військ;

- на стратегічному рівні - Воєнно-наукове управління Генерального штабу ЗС України.

3 початку створення 3С України і до квітня 2014 р. в діяльності СУПД можна виокремити два головні напрями: вивчення досвіду підготовки військ, зокрема досвіду військових навчань національного та міжнародного рівня; і вивчення досвіду застосування українських контингентів у міжнародних операціях із підтримання миру і безпеки (ОПМБ). На практиці особовий склад органів СУПД тільки частково був залучений до вивчення досвіду підготовки та застосування військ (сил). Це відбувалося, насамперед, через сталий занепад у підготовці військ, що характеризувався постійним зниженням кількості і масштабів національних військових навчань (Ісаков, Яковлев, Хлопецький, Василів, 2009: 152-155). Так, наприклад, із 1991 по 1995 рік у ЗС України було проведено тільки одне полкове (бригадне) навчання, і після цього до 2014 року військові навчання такого рівня і вище взагалі не проводилися (Wilk, 2017). Красномовними свідченнями низького рівня підготовки військ у той період були заголовки в офіційних засобах масової інформації, зокрема в газеті Міністерства оборони України „Народна армія”: „Замість полігона - плац”; „Заняття без моторесурсу" тощо (Ісаков, Яковлев, Хлопецький, Василів, 2009: 154). 
За умов відсутності належної підготовки особовий склад ЗС України не здобував необхідний досвід, а органи СУПД, що мали вивчати такий досвід, виконували зовсім інші завдання, що їм непритаманні.

На противагу вищезазначеному спостерігалася позитивна тенденція у сталому зростанні кількості та масштабу міжнародних військових навчань, включаючи навчання під егідою НАТО, до яких залучалися підрозділи ЗС України. Так, наприклад, у період iз 2006 по 2011 рік понад 23 тисячі українських військовослужбовців взяли участь у 95 багатонаціональних навчаннях, із яких 43 були проведені на території України (Воєнна історія, 2021). Неформальним вивченням досвіду проведення вказаних навчань зазвичай займався особовий склад відділів, управлінь бойової підготовки, оскільки йому було доручено безпосередню організацію таких міжнародних заходів $з$ української сторони.

Крім вивчення досвіду підготовки військ основна діяльність СУПД була сфокусована також на аналізі застосування українських контингентів i персоналу в ОПМБ. Україна стала активним учасником такої діяльності після затвердження Верховною Радою України Постанови від 3 липня 1992 року „Про участь батальйонів Збройних Сил України в Миротворчих Силах Організації Об'єднаних Націй у зонах конфліктів на території колишньої Югославії". Всього за 29 років майже 50000 українських військовослужбовців взяли участь більше ніж у 35 ОПМБ і, зокрема, у період з 2006 по 2011 рр. приблизно 6000 українських військовослужбовців виконували миротворчі завдання у складі 13 миротворчих місій в 11 країнах світу (Воєнна історія, 2021; Украӥнський прорив: Безпека й оборона, 2020).

Україна розглядала і продовжує розглядати участь у міжнародних ОПМБ як важливу складову своєї зовнішньої політики (Котелянець, 2012: 185-189). В умовах обмеженого державного фінансування сектору оборони участь українських військовослужбовців у миротворчих місіях сприяла покращенню підготовки військ, а також забезпечувала набуття бойового досвіду участі у збройних конфліктах як „третьої (миротворчої) сили”. Крім того, це сприяло формуванню спільноти військових фахівців, які отримали цінний досвід міжнародного співробітництва, що $\epsilon$ надзвичайно важливим надбанням для реформування та розвитку 3С України, налагодження військової співпраці з іноземними партнерами, насамперед зі збройними силами країн - членів НАТО. 
Варто зазначити, що до 2011 р. спостерігалися системні недоліки у підготовці до ОПМБ механізованих (піхотних) підрозділів ЗС України, насамперед у вивченні військовослужбовцями специфіки та тактики дій для виконання широкого спектру миротворчих завдань (Котелянець, 2012: 185-189). Деякі експерти пов' язували це $з$ низькою дієвістю вивчення і впровадження досвіду ОПМБ і зазначали, що однією з головних причин такого стану справ були бюрократичні перепони, а саме відсутність єдиного органу що керував би процесом вивчення і впровадження миротворчого досвіду. Зокрема для вирішення вказаних проблем, Наказом Міністра оборони України від 28.12.2011 р. № 840 було запроваджено Інструкцію 3 вивчення і впровадження досвіду підготовки та участі національних контингентів (персоналу) у міжнародних операціях 3 підтримання миру і безпеки. Відповідно до вимог даної Інструкції завдання 3 вивчення вищенаведеного досвіду покладалося головним чином на Національний університет оборони України імені I. Черняхівського та Центральний науково-дослідний інститут Збройних Сил України. Також у цьому документі було визначено основні процедури 3 вивчення і впровадження досвіду ОПМБ та обов'язки органів військового управління 3 їх виконання. Проте, у вказаній Інструкції не було представлено ні понятійного апарату, ні відповідних форм інформаційно-звітних документів із ВВД. У цьому контексті необхідно зауважити, що в Україні з 1991 по 2020 рік було відсутнє загальноприйняте бачення щодо процедур стандартизованого процесу УПД та методичних підходів до їх здійснення, оскільки у той період не було відповідної нормативної бази, зокрема сучасної концепції (доктрини) та інструкцій (настанов) з організації вивчення та впровадження досвіду.

Основними шляхами отримання інформації у 3С України щодо проблемних питань були:

- застосування напівформального методу збору спостережень, що містилися в інформаційно-звітних документах, наприклад, у звітах про підбиття підсумків діяльності, результати участі в ОПМБ, військових навчаннях тощо;

- збір і вивчення „неформальних" (ініціативних) спостережень, а також отримання інформації про досвід, наприклад, під час особистого спілкування, проведення навчальних занять тощо;

- вивчення результатів роботи дослідницьких груп, що формувалися 3 представників органів військового управління, закладів 
та установ 3С України, здійснювали дослідження специфічних проблем, аналіз причин їх виникнення та шляхів вирішення.

У той час, як в багатьох провідних країнах світу після завершення „холодної війни” спостерігався розвиток перманентного формального підходу до ВВД (Dyson, 2020: 15), організаційне вивчення та впровадження досвіду у ЗС України було у занепаді. Напівформальний метод ВВД, що застосовувався у спрощеному варіанті, передбачав згідно з табелем донесень подання ,знизувверх" інформації про досвід у визначених розділах загальних звітних документів, а також аналіз і поширення такої інформації. Ефективність такого підходу до ВВД була доволі низькою, передусім, через відсутність зацікавленості особового складу до збору та подання інформації з проблемних питань, небажання та безініціативність певних посадових осіб щодо вивчення досвіду; а також через низьку якість аналізу та узагальнення інформації щодо проблеми, визначення головних причин виникнення та шляхів вирішення. На практиці здобута інформація про досвід послідовно передавалася через інстанції ,знизу-вверх", проте не оброблялася належним чином і після чого поширювалася „вниз” та використовувалася, в основному, як довідковий матеріал.

Власне вивченням та впровадженням досвіду мали займатися всі командири і начальники, а також більшість офіцерів ЗС України, оскільки до їх функціональних обов'язків було включено ці питання. Проте, відповідно до принципу „всі і ніхто” функціонування СУПД можна оцінити швидше як декларування діяльності, ніж іiі продумане та ефективне здійснення. Про це свідчить також той факт, що основними документами для вивчення офіцерами ЗС України був нескінченний потік інформаційних повідомлень 3 вищих штабів із „голим” наведенням фактів про злочини, зловживання та грубі порушення військової дисципліни, надзвичайні події за участі військовослужбовців (Ісаков, Яковлев, Хлопецький, Василів, 2009: 152-156). На противагу цьому значно менш частими були випадки доведення до особового складу ЗС України повчальних уроків і передового досвіду у підготовці та застосуванні військ. Крім того, варто зазначити, що вивчення бойового досвіду збройних сил інших держав за політичною інерцією здійснювалося крізь призму стратегічного бачення та національних інтересів Російської Федерації, базуючись на використанні головним чином російських джерел інформації. 
Із метою поширення як негативного, так і позитивного досвіду використовувалися наради (брифінги); підбиття підсумків діяльності (виконання завдань); друковані видання (настанови, порадники, посібники тощо); засоби масової інформації (спеціалізовані газети та радіотелевізійні передачі); інтернет і спеціалізовані вебсайти тощо. Через недостатнє фінансування впровадження сучасних новітніх інформаційних технологій (ІКТ) відбувалося надто повільно зі значним відставанням від інших передових держав. Так, наприклад, у ЗС України до 2017 року була відсутня база даних, що містила б інформацію про здобутий досвід (Пашук, Пашковський, 2019: 36-39), у той час як країнах - членах НАТО ще з 2005 року функціонувала подібна база даних, на основі якої у 2010 році було створено „он-лайн” Портал НАТО (15 Years of the JALLC, 2017: 33). Також це стосувалося малих тиражів друкованих видань із питань УПД; низьких темпів створення та використання спеціалізованих комп'ютерних мереж як відкритих, так і захищених (з обмеженим доступом). Поза тим, також можна конятатувати низький рівень підготовки особового складу ЗС України 3 питань УПД, відсутність дієвої системи підготовки персоналу органів УПД передусім через те, що взагалі не було жодних навчальних курсів підготовки фахівців з узагальнення та поширення досвіду.

Основним чинником реформування СУПД, яке розпочалося у травні 2013 року, була необхідність підвищення рівня бойової підготовки Збройних Сил України, що не можливо було досягти за незадовільного стану функціонування вказаної системи. Крім того, у рамках військового співробітництва України 3 НАТО партнери наполегливо рекомендували ЗС України здійснити якісні зміни в ОВВД відповідно до сучасних досягнень у теорії та передовій практиці інших країн. На підставі раніше досягнутих домовленостей із Військовим комітетом Альянсу з 13 по 15 травня 2013 року у Бельгії була проведена зустріч військового керівництва України та НАТО на рівні начальників Генеральних штабів із питань співробітництва у сфері ВВД (Протокол наради, 2014: 1-5). У подальшому відповідно до прийнятих рішень було сформовано аналітичну групу, що виконала грунтовний аналіз функціонування СУПД із іi порівнянням із Об'єднаною системою ВВД НАТО, на підставі чого були визначено основні проблемні питання (Протокол наради, 2014: 1-5):

- відсутність централізованої організаційної структури СУПД; 
- відсутність концепції ВВД, а також оновлених інструкцій 3 організації даного процесу;

- відсутність системи підготовки особового складу ЗС України 3 питань ВВД;

- надто повільно впроваджувалися новітні IКТ для збору та оброблення інформації з досвіду, а також для ії поширення;

- командири і начальники не здійснювали на належному рівні керівництво процесом ВВД;

- не вивчалася передова практика передових країн із організаційного ВВД.

За результатами вищенаведеного аналізу було зроблено висновок про низьку ефективність функціонування СУПД. Вивчення (ідентифікація) уроків і потенційного передового досвіду, розроблення i реалізація заходів із впровадження досвіду здійснювалися неякісно, а поширення уроків виконувалося несвоєчасно і не серед усього особового складу, що потребував такої інформації. Вищезазначена діяльність мала безсистемний характер, а управління нею було фрагментарним.

Серед головних причин такого стану справ було визначено бюрократичні перепони та соціально-психологічні чинники, що проявлялися у нерозумінні командирами та начальниками важливості та пріоритетності УПД, а також у небажанні очолювати удосконалення СУПД. Щоб виправити вказану ситуацію, 27 січня 2014 року було проведено робочу нараду керівного складу 3С України, за результатами якої було визначено необхідність корегувальних заходів із урахуванням рекомендацій вищевказаної групи (Протокол наради, 2014: 1-5):

- створити у складі Воєнно-наукового управління Генерального штабу ЗС України (ВНУ ГШ) групу організації вивчення й узагальнення передового досвіду (2 офіцери) і призначити це управління відповідальним за організацію та координацію вивчення та поширення досвіду у ЗС України;

- сформувати відповідні органи (підрозділи) 3 вивчення досвіду на базі науково-дослідних установ і Центру оперативних стандартів і методики підготовки військ (сил) ЗС України, що мають здійснювати аналіз інформації про досвід і розроблення відповідних рекомендацій за напрямами діяльності;

- покласти на Військовий інститут Київського Національного університету імені Тараса Шевченка завдання щодо створення та 
технічного забезпечення Інтерактивної електронної бази даних 3 питань досвіду.

По суті це були недосконалі рішення щодо створення дієвої системи ВВД, оскільки не планувалося розроблення доктрини та інструкції із ВВД, а також створення централізованої організаційної структури. Крім того, залишався поділ органів ВВД на дві окремі „гілки”, між якими не було налагоджено чіткої взаємодії.

Висновки. Результати аналізу функціонування Системи узагальнення та поширення досвіду ЗС України впродовж двох етапів свого розвитку - „стагнація” (грудень 1991 - травень 2013) та „реформування” (травень 2013 - квітень 2014) свідчать про іï низьку дієвість. У ході дослідження розглянуто чотири основні компоненти вказаної Системи: організаційна структура, формалізовані процедури, засоби та підготовка особового складу щодо узагальнення та поширення досвіду.

Одним із головних наслідків неефективності вищезазначеної Системи було те, що у ЗС України вельми повільно впроваджувалися новації за результатами вивчення як свого досвіду, так і досвіду інших держав. Розроблення доктрин і статутів, підготовка військ та військова освіта здійснювалися за старими ,радянськими” стандартами з епохи „холодної війни” без урахування нових геополітичних реалій і змін у формах і способах ведення воєнних операцій (дій). Як результат, у Збройних Силах України не було проведено кардинальних реформ для їх адаптації до тодішнього стратегічного середовища, українські війська (сили) не були готові до ведення сучасних швидкоплинних воєнних операцій (дій).

\section{Використані посилання}

Біла книга 2010. Збройні Сили України (2011). Київ: Міністерство оборони України, 79 с.

Воєнна історія (2021). Офіційний сайт Міністерства оборони України. URL: https://www.mil.gov.ua/ministry/istoriya.html

Грицюк В. М., Євсєєв І. Г. (2020). Трансформація органів РобітничоСелянської Червоної Армії з вивчення та використання бойового досвіду у роки Другої світової війни. Воєнно-історичний вісник. Вип. 1 (35). С. 85-100.

Ісаков М., Яковлев М., Хлопецький О., Василів Ю. (2009). Аналіз існуючої системи аналізу і узагальнення досвіду підготовки військ в об' єднаних збройних силах НАТО та Сухопутних військах Збройних Сил України. Збірник наукових праць Харківського університету Повітряних Сил, Вип. 4 (22). С. 150-156.

Котелянець О. (2012). Актуальні питання розвитку міжнародної миротворчої діяльності України. Стратегічні пріоритети. Наиіональний інститут стратегічних досліджень. № 2 (23). С. 185-190. 
Обобщение боевого опыта и доведение его до войск Красной Армии и Сил Флота (2015). Великая Отечественная война 1941-1945 г2. В 12 m. Том 11. Политика и стратегия Победы: стратегическое руководство страной и Вооруженными силами СССР в годы войны. Москва: Воениздат. С. 695-776.

Пащук Ю., Пашковський В. (2019). Методологічні підходи до формування у Збройних Силах України перспективної системи вивчення i впровадження досвіду. Наука і техніка Повітряних Сил Збройних Сил Украӥни, № 4 (37), С. 36-43.

Про затвердження Інструкиії з організаџї участі національних контингентів (персоналу) Збройних Сил Украӥни у міжнародних операчіях із підтримання миру і безпеки. Наказ Міністра оборони України від 28.12.2011 p. № 840. 21 с.

Протокол наради керівного складу Збройних Сил Украӥни щзодо створення системи вивчення та узагальнення передового досвіду у Збройних Силах України від 27 січня 2014 р. (2014), Київ: Воєнно-наукове управління Генерального штабу Збройних Сил України, 5 с.

Український прорив: Безпека й оборона (2020). URL: https://www.ukrinform.ua/ rubric-society/3085312-ukrainskij-proriv-bezpeka-j-oborona.html

15 Years of the JALLC - NATO (2017). Lisbon: NATO Joint Analysis and Lessons Learned Centre, $160 \mathrm{p}$.

Cyert R., March J. (1963). A Behavioral Theory of the Firm. Englewood Cliffs, NJ: Prentice-Hall, 332 p.

Dyson T. (2019). The Military as a learning organisation: establishing the fundamentals of best-practice in lessons-learned. Defence Studies. Vol. 19. Iss. 2, pp. 107-129.

Dyson T. (2020). Organisational Learning and the Modern Army. A New Model for Lessons-Learned Processes. 1st Edition. London: Routledge, 276 p.

The NATO Lessons Learned Handbook. Third Edition. (2016). Lisbon: NATO Joint Analysis and Lessons Learned Centre, $81 \mathrm{p}$.

Wilk A. (2017). The best army Ukraine has ever had. Changes in Ukraine's armed forces since the Russian aggression. Warsaw: Centre for East Studies. 44 p.

\section{References}

15 Years of the JALLC - NATO (2017). Lisbon: NATO Joint Analysis and Lessons Learned Centre, $160 \mathrm{p}$.

Cyert R., March J. (1963). A Behavioral Theory of the Firm. Englewood Cliffs, NJ: Prentice-Hall, 332 p.

Dyson T. (2019). The Military as a learning organisation: establishing the fundamentals of best-practice in lessons-learned. Defence Studies. Vol. 19. Iss. 2, pp. 107-129.

Dyson T. (2020). Organisational Learning and the Modern Army. A New Model for Lessons-Learned Processes. 1st Edition. London: Routledge, 276 p.

Hrytsiuk V., Yevsieiev I. (2020). Transformation of the Lessons Learned organisational structure within Red Army in the Second World War. Military Scientific Journal. Kyiv, National Defence University of Ukraine. Vol. 1(35) / 2020. pp. 85-100. [In Ukrainian]

Isakov M., Yakovlev M., Khlopetsky O., Vasyliv Y. (2009). Analysis of the existing system of analysis and generalization of the experience of training in the Allied Forces and the Land Forces of the Armed Forces of Ukraine. Collection of scientific works. Kharkiv, National Air Force University. 2009, 4 (22). pp. 150-156. [In Ukrainian] 
Kotelyanets O. (2012). Current issues of international peacekeeping activity in Ukraine. Strategic priorities. National Institute for Strategic Studies. 2012. № 2 (23). pp. 185-190. [In Ukrainian]

Military History (2021). Official site of the Ministry of Defense of Ukraine. URL: https://www.mil.gov.ua/ministry/istoriya.html. [In Ukrainian].

On approval of the Instruction on organizing of participation of national contingents (personnel) of the Armed Forces of Ukraine in international peace support operations. Order of the Minister of Defense of Ukraine dated 28.12.2011 № 840. 21 p. [In Ukrainian].

Pashchuk Y., Pashkovskyi V. (2019). Methodological approach to forming Prospective Lessons Learned System in the Ukrainian Army. Science and Technology of the Air Force of Ukraine. Kharkiv, National Air Force University. Vol. 4 (37), 2019. pp. 36-43. [In Ukrainian].

Protocol of the meeting of the Ukrainian Armed Forces on creation of lessons learned system in the Armed Forces of Ukraine on January 27, 2014. (2014), Kyiv: Military-Scientific Department of the General Staff of the Armed Forces of Ukraine, 5 p. [In Ukrainian].

Analysis of combat experience and disseminating it to the troops of the Red Army and Navy Forces (2015). The Great Patriotic War of 1941-1945. In 12 volumes. Volume Eleventh. Policy and Strategy of the Victory: strategic leadership of the country and the Armed Forces of the USSR during the War. Moscow: Voyenizdat. pp. 695-776. [In Russian].

The NATO Lessons Learned Handbook. Third Edition. (2016). Lisbon: NATO Joint Analysis and Lessons Learned Centre, $81 \mathrm{p}$.

Ukrainian breakthrough: Security and defense (2020). URL: https://www.ukrinform.ua/ rubric-society/3085312-ukrainskij-proriv-bezpeka-j-oborona.html. [In Ukrainian].

Wilk A. (2017). The best army Ukraine has ever had. Changes in Ukraine's armed forces since the Russian aggression. Warsaw: Centre for East Studies. 44 p.

White book 2010. The Armed Forces of Ukraine (2011). Kyiv: Ministry of Defense of Ukraine, 79 p. [In Ukrainian].

\section{Pashchuk Y. \\ HISTORICAL ASPECTS OF ORGANIZATIONAL LEARNING IN THE UKRAINIAN ARMED FORCES IN PEACTIME (1991-2014)}

This paper presents historical aspects of creation and performance of the System of lessons analysis and dissemination in the Armed Forces of Ukraine in peacetime starting from their creation in December 1991 till April 2014 when the Anti-terrorist operation in the Eastern Ukraine began.

The article contains an assessment of functioning the System of lessons analysis and dissemination during two of the three main stages of its formation and development in accordance with geopolitical changes and reforms of the Ukrainian Armed Forces: Stagnation stage (December 1991- May 2013) and Reformation stage (May 2013-April 2014).

A need to research the history of organizational learning in the Armed Forces of Ukraine and study peculiarities of the System of lessons analysis and dissemination is primarily due to the fact that since January 2019 the Ukrainian Army started to build a new prospective Lessons Learned System based on the above-mentioned System. 
An importance and relevance of this scientific and practical task is also determined by an absence of tailored studies in the Ukrainian historiography.

The work describes four main components of the System of lessons analysis and dissemination: organizational structure; process (procedures) of organizational learning; tools used to collect, analyze and disseminate experience. The research was focused in two main directions of knowledge acquisition: training, in particular, military exercises at the national and international level and employment of the Ukrainian contingents in peace support operations.

Based on the analysis, a conclusion has been made about low efficiency of the System of lessons analysis and dissemination in the peacetime (December 1991 April 2014). As a result, innovations came in the Ukrainian Armed Forces very slowly and developing doctrines, troops training and officers' education were still performed depending on the old Soviet standards from the Cold War era without taking into account new geopolitical realities and changes in forms and methods of contemporary military operations. Accordingly, there was no radical modernization of the Ukrainian Armed Forces, and the Ukrainian troops were not ready to respond to multiple challenges.

Keywords: experience, organizational learning, lessons learned process, System of lessons analysis and dissemination, the Armed Forces of Ukraine. 